\title{
Epistatic Interactions Influencing Anthocyanin Gene Expression in Capsicum annuum
}

\author{
Gordon J. Lightbourn \\ Biological Sciences Department, Virginia Polytechnic Institute and State University, Blacksburg, \\ VA 24061 \\ John R. Stommel ${ }^{1}$ \\ U.S. Department of Agriculture, Agriculture Research Service, Beltsville Agricultural Research \\ Center, Genetic Improvement of Fruits and Vegetables Laboratory, Plant Science Institute, \\ Beltsville, MD 20705 \\ Robert J. Griesbach \\ U.S. Department of Agriculture, Agriculture Research Service, Beltsville Agricultural Research \\ Center, Floral and Nursery Plant Research Unit, United States National Arboretum, Beltsville, \\ MD 20705
}

\begin{abstract}
AdDitional INDEX words. Ans, Chs, delphinidin, $D f r$, Myb, Myc, pepper, WD40
Abstract. Anthocyanin pigmentation in leaves, flowers, and fruit imparts violet to black color and enhances both ornamental and culinary appeal. Shades of violet to black pigmentation in Capsicum annuum L. are attributed to anthocyanin accumulation. Anthocyanin production is markedly influenced by numerous environmental factors, including temperature and light stress. The objective of this study was to determine the genetic basis for differences in $C$. annuum anthocyanin content in response to varying environments. Growth experiments conducted under controlled environment conditions demonstrated that anthocyanin concentration was significantly higher in mature leaves in comparison with immature leaves under high light $\left(435 \mu \mathrm{mol} \cdot \mathrm{s}^{-1} \cdot \mathrm{m}^{-2}\right)$ conditions. High $\left(30{ }^{\circ} \mathrm{C}\right.$ day $/ 25{ }^{\circ} \mathrm{C}$ night) versus low $\left(20^{\circ} \mathrm{C}\right.$ day $/ 15^{\circ} \mathrm{C}$ night) temperature had no significant effect on anthocyanin concentration regardless of leaf maturity stage. Foliar anthocyanin concentration in plants grown under short days $(10 \mathrm{~h})$ with low light intensity $\left(215 \mu \mathrm{mol} \cdot \mathrm{s}^{-1} \cdot \mathrm{m}^{-2}\right)$ was significantly less than under long days $(16 \mathrm{~h})$ with low light. Under high light intensity, daylength had no effect on anthocyanin content. Three structural genes [chalcone synthase (Chs), dihydroflavonol reductase $(D f r)$, anthocyanin synthase $(A n s)]$ and three regulatory genes $\left(M y c, M y b_{A}, W d 40\right)$ were selected for comparison under inductive and noninductive environmental conditions for anthocyanin accumulation. Expression of $C h s, D f r$, and $A n s$ was significantly higher in mature leaves in comparison with younger leaves. Consistent with anthocyanin concentration, temperature had no effect on structural gene expression, whereas light positively influenced expression. Under low light conditions, temperature had no effect on $M y c, M y b_{A}$, and $W d 40$ expression; whereas under high light conditions, temperature only had an effect on $M y b_{A}$ expression. The study of anthocyanin leaf pigmentation in $C$. annuum under inductive and noninductive environments provides a new approach for elucidating the molecular genetic basis of epistatic gene interactions and the resulting phenotypic plasticity.
\end{abstract}

Capsicum annuum (pepper) is cultivated as both an ornamental and a vegetable. Anthocyanin pigmentation in leaves, flowers, and fruit imparts violet to black color and enhances both ornamental and culinary appeal. Anthocyanins are the end product of the flavonoid biosynthetic pathway. This pathway has been extensively studied in many species (Griesbach, 2005; Winkel-Shirley, 2001). Anthocyanin pigments have key roles in plants for their function in attraction of pollinators and seed dispersers. These compounds also function as ultraviolet protectants, antimicrobial agents, and feeding deterrents, in signaling between plants and microbes, and in male fertility of some species (Winkel-Shirley, 2001). There is considerable interest in anthocyanins and other flavonoids for their potential

Received for publication 1 Mar. 2007. Accepted for publication 12 July 2007. This work was supported by a Cooperative Research and Development Agreement (58-3K95-5-1074) with Kerry's Bromeliad Nursery and McCorkle Nursery.

Mention of trade names or commercial products is solely for the purpose of providing specific information and does not imply recommendation or endorsement by the U.S. Department of Agriculture.

${ }^{1}$ Corresponding author. E-mail: john.stommel@ars.usda.gov. health benefits (Nijveldt et al., 2001). The anthocyanin expressed in the leaves, stems, flowers, and fruit of C. annuиm is delphinidin-3-p-coumaroylrutinosyl-5-glucoside (Lightbourn et al., 2007).

Anthocyanin structural gene transcription requires the expression of at least one of each of three distinct transcription factor families: MYC, MYB, and WD40 (Griesbach, 2005). The $M y c$ gene family encode proteins characteristic of human MYC oncoprotein transcription factors (Buck and Atchley, 2003). MYC is defined by an N-terminal end of $\approx 20$ hydrophilic basic amino acids and a C-terminal end of $\approx 40$ hydrophobic amino acids that form a basic helix-loop-helix structure.

The $M y b$ gene family encodes proteins characteristic of human MYB oncoprotein transcription factors (Borevitz et al., 2000; Stracke et al., 2001). MYB is defined by an Nterminal end rich in basic amino acids and a $\mathrm{C}$-terminal end rich in acidic amino acids. MYBs are classified into three subfamilies based upon the number of adjacent repeats in the MYB domain: MYB1R (one repeat), R2R3-MYB (two repeats), and MYB3R (three repeats). The R2R3 class is involved in anthocyanin expression. 
The WD40 family encode proteins characteristic of the $\beta$-propeller group. WD40 is defined by a 40-residue core region delineated by a glycine-histidine dipeptide and a tryptophanaspartic acid (WD) dipeptide. This motif is repeated in tandem 4 to 16 times (Smith, 1999).

The three transcription factors (MYC, MYB, and WD40) form a complex that binds to structural gene promoters, thus modulating gene expression. The following description of this complex was complied from several sources (Baudry et al., 2006; Hartmann et al., 2005; Hernandez et al., 2004; Ramsay and Glover, 2005; Zimmermann et al., 2004). MYC associates with WD40. Either before or after its association with WD40, MYC binds to the amino acid sequence (DE) $\mathrm{Lx}_{2}(\mathrm{RK}) \mathrm{x}_{3} \mathrm{Lx}_{6} \mathrm{Lx}_{3} \mathrm{R}$ on helixes 1 and 2 of the $\mathrm{R} 3$ repeat in MYB. Once associated, MYB binds to the structural gene promoter's MYB recognition element containing the consensus nucleotide sequence AACCTA. MYC binds to the promoter's E-box containing the nucleotide consensus sequence CAGCTG. In addition to anthocyanin biosynthesis, this transcription factor complex regulates the expression of multiple target genes that determine epidermal cell specialization in plants (Ramsay and Glover, 2005). The role of the MYC, MYB, WD40 complex in determining genetic epistasis and the resulting phenotypic plasticity are key contributors to the evolution of cellular diversity in plants.

Anthocyanin pigmentation in C. annuum is influenced by an incompletely dominant gene, Anthocyanin (A) (Peterson, 1959). A second gene, modifier of $A(M o A)$, intensifies the purple color in the presence of $A$ (Deshpande, 1933). The $A$ locus encodes a $M y b$ transcription factor $\left(M y b_{A}\right)$ that is absent in genotypes that do not accumulate anthocyanin (Borovsky et al., 2004).

The objective of this study in $C$. annuum was to investigate the genetic basis for differences in anthocyanin expression under different environmental conditions. Expression of anthocyanin structural and regulatory genes in response to varied light and temperature conditions was characterized. The role of the MYC, MYB ${ }_{\mathrm{A}}$, WD40 transcription factor complex in determining anthocyanin pigmentation is discussed.

\section{Materials and Methods}

Plant material and growing conditions. Capsicum annuum plants of the true breeding genotype G02C27 were produced from seed germinated under standard greenhouse growth conditions (Stommel and Bosland, 2006). G02C27 characteristically bears black foliage and black immature fruit under optimal growth conditions. Transplants were transferred to $15.2-\mathrm{cm}$-diameter pots $(1.32 \mathrm{~L})$ in a commercial peat-based mix (Metro-Mix; Sun Gro Horticulture, Bellevue, WA) at the four-true-leaf stage and moved to controlled environment chambers with variable light and temperature conditions. Conditions included high, medium, or low temperature $\left(30{ }^{\circ} \mathrm{C}\right.$ day $/ 25{ }^{\circ} \mathrm{C}$ night, $23{ }^{\circ} \mathrm{C}$ day $/ 18{ }^{\circ} \mathrm{C}$ night, or $20{ }^{\circ} \mathrm{C}$ day $/$ $15{ }^{\circ} \mathrm{C}$ night), high or low light intensity (435 or 215 $\left.\mu \mathrm{mol} \cdot \mathrm{s}^{-1} \cdot \mathrm{m}^{-2}\right)$, and long or short days $(10$ or $16 \mathrm{~h})$ in all possible combinations. Leaves were harvested from each of five plants after 3 to 4 months of growth under defined conditions.

Anthocyanin anAlysis. Leaves were pressed between two sheets of Whatman no. 2 filter paper using a roller press (Ravenel Specialties Co., Seneca, SC). The filter paper sheet with the upper epidermal impression was soaked in chloroform for 15 min to clear the image of chlorophyll, and then was dried and photographed.

The degree of anthocyanin pigmentation was measured through digital analysis using Paint Shop Pro v. 7.02 (Corel Corp., Ottawa, ON, Canada) and Scion Image v. 4.03 (Scion Corp., Frederick, MD). Using Paint Shop Pro, the color saturation of the cleared leaf image was increased and the image was reduced to grayscale. Using Scion Image, the grayscale image was reduced to black and white, and the number of black pixels was determined as a measure of anthocyanin concentration. Measurements from five different leaves per plant were averaged and compared across treatments.

RNA ANALYsis. Flavonoid gene expression [MYC, MYB, and WD transcription factors, anthocyanin synthase (Ans), dihydroflavonol reductase $(D f r)$, and chalcone synthase $(C h s)$ ] was compared under inductive and noninductive environments for anthocyanin pigmentation. About $100 \mathrm{mg}$ fresh weight leaf tissue was frozen in liquid nitrogen and stored at $-70{ }^{\circ} \mathrm{C}$. RNA was isolated from the frozen leaf tissue using Rneasy Plant Mini Kit with the optional DNase digest (Qiagen, Valencia, CA).

Capsicum annuum-specific primers were used for $M y b$ identification (Borovsky et al., 2004); whereas degenerate primer sets from Petunia $\times$ hybrida Vilm. (Griesbach and Beck, 2005) were initially used for all the other genes. The polymerase chain reaction (PCR) products from the degenerate primers were cloned and sequenced to identify gene-specific products. The sequences were used to design $C$. annuum genespecific primers, with the exception of tubulin $(T u b)$, for which the primer design was based solely on gene sequences reported in GenBank. The $C$. annuum-specific primer sets were as follows: The forward Chs primer was 5'-GTG GAA CCG TTA TCC GAC TAG CAA-3' and the reverse primer was 5' GTA TCA CTT GGG CCA CGG AAA GTA-3', the forward Dfr primer was 5' -AAT CGC TCC AGC TGG TCT CAT CAT$3^{\prime}$ and the reverse primer was 5' -CTA ACA CAG GGA AGA GGC TGG TTT-3', the forward Ans primer was 5' -CAA ATG CCC ACA ACC AGA ACT AGC-3' and the reverse primer was 5'-CGC ACT TTG CAG TTA CCC ACT TTC-3', the forward Tub primer was 5' -CCC TGT GAA ATA AGG CGG TTC AGA-3' and the reverse primer was 5'-AAC AGT GTC CTG TCA ACT CAC TCC-3', the forward $M y c$ primer was 5'-CAA TGG AGC TAT AAA GAC TAG GAA-3' and the reverse primer was 5' -GGA AAA GAG AAA GAA ACA CAC ATG-3', the forward $W d 40$ primer was $5^{\prime}-\mathrm{GTG}$ TGA ATG CTA TTG CTT GG-3' and the reverse primer was 5'-GGA GGA GGA CCA CTG AAG-3', and the forward $M y b_{A}$ primer was 5'-GAT ATC ATG AAT ACT GCT ATT-3' and the reverse primer was $5^{\prime}$-CTT ACA TTG AAG ATG CGT GGA3'. Real-time PCR was used to analyze gene expression. Complementary DNA (cDNA) synthesis was performed with $1 \mu \mathrm{g}$ RNA using the iScript cDNA Synthesis Kit (BIO-RAD, Hercules, CA). Amplification of the cDNA was carried out using the iCycler 1Q Multicolor Real-Time Detection System (BIO-RAD). A two-step PCR protocol was used, consisting of 1 cycle of $95^{\circ} \mathrm{C}$ for $30 \mathrm{~s}, 50$ cycles of denaturation at $95^{\circ} \mathrm{C}$ for $10 \mathrm{~s}$, and an anneal/extension of $60{ }^{\circ} \mathrm{C}$ for $45 \mathrm{~s}$. This was followed by melt curve validation: 1 cycle of $95{ }^{\circ} \mathrm{C}$ for $1 \mathrm{~min}$, 1 cycle of $55^{\circ} \mathrm{C}$ for $1 \mathrm{~min}$, then 80 cycles of a set point temperature increase of $0.5^{\circ} \mathrm{C}$ in 10 -s increments from $55^{\circ} \mathrm{C}$. The detection and amplification of PCR product was made with iQ SYBR Green Super mix reagents (BIO-RAD) using 
$50 \mathrm{ng} /$ reaction of cDNA template, and $0.2 \mu \mathrm{L}$ of $10 \mu \mathrm{M}$ primer stock, in a total volume of $20 \mu \mathrm{L}$.

In preliminary real-time PCR experiments, standard calibrations were computed and the efficiency of reaction kinetics and $R$ values were tabulated and found to fall within the range of $95 \%$ to $105 \%$ (efficiency) and 0.98 to 1.0 ( $R$ value). Threshold values (iQ, $5 \mathrm{v} 2.0)$ were manually checked for an SD more than 0.5 within triplicate reactions. Normalized relative fold expression values were derived via the Pfaffl method (Pfaffl, 2001) and imported into SigmaStat 3.1 (Systat Software, San Jose, CA). Pairwise comparisons between means were made using $t$ tests.

Polymerase chain reaction products were cloned and sequenced to verify their identity. They were cloned using the TOPO-TA Kit (Invitrogen, Carlsbad, CA). Plasmid DNA was purified using Genelute Plasmid Mini-Prep Kit (Sigma, St. Louis) and commercially sequenced.

\section{Results}

We observed that the intensity of foliar anthocyanin pigmentation varied under different light and temperatures. Growth experiments under controlled environmental conditions were carried out to characterize the environmental response of anthocyanin pigmentation.

Anthocyanin concentration could not be measured directly. The standard procedure for extracting anthocyanin uses acidic alcohols, such as $1 \% \mathrm{HCl}$ in methanol. When young green leaves were extracted in $1 \% \mathrm{HCl}$, extracts turned purple. This suggests that the colorless leucoanthocyanins are present in immature green tissue. Leucoanthocyanins are converted into colored anthocyanins by acid (Sheridan and Mills, 1998). Therefore, a new approach based upon differential solubility of plastid pigments and anthocyanin was used to measure the amount of purple pigment (see Materials and Methods for details). Using a leaf press, pigments from leaves were transferred to filter paper. The plastid pigments were then removed by soaking the filter paper in chloroform. Plastid pigments, unlike anthocyanin pigments, are only soluble in organic solvents like chloroform. Digital photographs were taken of the resulting cleared images. The digital images were converted to black and white, and the number of black pixels was measured to make relative comparisons between samples, similar to those procedures used in quantifying band intensity on electrophoretic gels. Even though pixel number may not obey Beer's law (i.e., twice as many pixels equals twice as much anthocyanin), an increase in pixel number represents a relative increase in anthocyanin content).

Preliminary experiments indicated that under low light conditions $\left(10 \mathrm{~h}\right.$ of $215 \mu \mathrm{mol} \cdot \mathrm{s}^{-1} \cdot \mathrm{m}^{-2}$ cool-white fluorescent light supplemented with incandescent), irrespective of temperature, very little anthocyanin pigmentation occurred, in contrast with pigmentation observed under high light conditions $(16 \mathrm{~h}$ of $435 \mu \mathrm{mol} \cdot \mathrm{s}^{-1} \cdot \mathrm{m}^{-2}$ cool-white fluorescent light supplemented with incandescent). Therefore, initial experiments that evaluated anthocyanin accumulation as a function of leaf development used high light conditions. Leaves were collected from four different stages of development. Stage 1 was defined as an immature 1-cm-long leaf; stage 4 was a fully expanded leaf three internodes below the stage 1 leaf. Stage 2 and stage 3 leaves were the corresponding leaves at internodes 1 and 2 .
Under high light conditions at both high and low temperatures, there was no statistically significant difference in anthocyanin concentration between the first three stages of leaf development (Table 1). There was a significant difference between stage 4 and the other stages at both high and low temperatures. Anthocyanin concentration increased about two to threefold between stage 1 and stage 4 leaves. In addition, there was no statistically significant difference between any of the corresponding stages of development at high and low temperatures. Under high light conditions, temperature had no effect on anthocyanin pigmentation.

The influence of light duration and light intensity on anthocyanin pigmentation of stage 4 leaves was then investigated. Because temperature had no statistically significant effect on pigmentation, further experiments were conducted at $23{ }^{\circ} \mathrm{C}$ day and $18{ }^{\circ} \mathrm{C}$ night for improved plant growth and health. Anthocyanin pigmentation was evaluated under four different light conditions: short daylength, low light intensity (10 h of $215 \mu \mathrm{mol} \cdot \mathrm{s}^{-1} \cdot \mathrm{m}^{-2}$ cool-white fluorescent light supplemented with incandescent); short daylength, high light intensity (10 h of $435 \mu \mathrm{mol} \cdot \mathrm{s}^{-1} \cdot \mathrm{m}^{-2}$ light); long daylength, low light intensity ( $16 \mathrm{~h}$ of $215 \mu \mathrm{mol} \cdot \mathrm{s}^{-1} \cdot \mathrm{m}^{-2}$ light); and long daylength, high light intensity ( $16 \mathrm{~h}$ of $435 \mu \mathrm{mol} \cdot \mathrm{s}^{-1} \cdot \mathrm{m}^{-2}$ light). The anthocyanin concentration of leaves from plants grown under $10 \mathrm{~h}$ of low light (34 pixels $/ \mathrm{mm}^{2}$ anthocyanin) was significantly less $(P=0.001), \approx 10$-fold, than under $16 \mathrm{~h}$ of low light (361 pixels $/ \mathrm{mm}^{2}$ anthocyanin; Table 2). Under high light intensity, the light duration (10 h vs. $16 \mathrm{~h}$ ) had no effect. Phenotypes elicited by extremes of temperature and light conditions are shown in Fig. 1.

To deduce a molecular genetic basis for the environmental effects observed, gene expression studies were performed under inductive and noninductive environmental conditions for anthocyanin accumulation. Three anthocyanin biosynthetic structural genes (Chs, $D f r$, and $A n s)$ and three transcription factor regulatory genes $\left(M y c, M y b_{A}\right.$, and $\left.W d 40\right)$ were selected for comparison.

Because anthocyanin accumulation was the highest under high light conditions $\left(16 \mathrm{~h}\right.$ of $435 \mu \mathrm{mol} \cdot \mathrm{s}^{-1} \cdot \mathrm{m}^{-2}$ cool-white fluorescent light supplemented with incandescent) and growth was the fastest under high temperature $\left(30^{\circ} \mathrm{C}\right.$ day and $25^{\circ} \mathrm{C}$ night), the first series of experiments investigated gene expression during leaf development under high light and temperature

Table 1. Anthocyanin concentration of Capsicum annuum 'G02C27' leaves from different stages of development.

\begin{tabular}{lcc}
\hline & \multicolumn{2}{c}{ Anthocyanin concn $\left[\right.$ mean \pm SE $\left(\right.$ pixels $\left.\left./ \mathrm{mm}^{2}\right)\right]$} \\
\cline { 2 - 3 } Stage & $20{ }^{\circ} \mathrm{C}$ day $/ 18{ }^{\circ} \mathrm{C}$ night & $30{ }^{\circ} \mathrm{C}$ day $/ 28{ }^{\circ} \mathrm{C}$ night \\
\hline 1 & $108 \pm 70 \mathrm{a}^{z}$ & $89 \pm 70 \mathrm{a}$ \\
2 & $79 \pm 61 \mathrm{a}$ & $143 \pm 68 \mathrm{a}$ \\
3 & $82 \pm 41 \mathrm{a}$ & $169 \pm 66 \mathrm{a}$ \\
4 & $217 \pm 22 \mathrm{~b}$ & $247 \pm 8 \mathrm{~b}$
\end{tabular}

${ }^{\mathrm{z}}$ Means followed by the same letter within an individual temperature treatment are not significantly different according to the Fisher LSD pairwise multiple comparison test $(P=0.009)$.

Stage 1 was defined as an immature, 1 -cm-long leaf and stage 4 was a fully expanded leaf three internodes below the stage 1 leaf. Stages 2 and 3 leaves were the corresponding leaves at internodes 1 and 2 . Plants were grown under $16 \mathrm{~h}$ of $435 \mu \mathrm{mol} \cdot \mathrm{s}^{-1} \cdot \mathrm{m}^{-2}$ cool-white fluorescent light supplemented with incandescent light. 
Table 2. Anthocyanin concentration of stage 4 leaves was measured from Capsicum annuum ' $\mathrm{G} 02 \mathrm{C} 27$ ' plants grown at $23{ }^{\circ} \mathrm{C}$ day $/ 18^{\circ} \mathrm{C}$ night under four different light conditions: short daylength and low light intensity $\left(10 \mathrm{~h}\right.$ of $215 \mu \mathrm{mol} \cdot \mathrm{s}^{-1} \cdot \mathrm{m}^{-2}$ cool-white fluorescent light supplemented with incandescent), short daylength and high light intensity $\left(10 \mathrm{~h}\right.$ of $\left.435 \mu \mathrm{mol} \cdot \mathrm{s}^{-1} \cdot \mathrm{m}^{-2}\right)$, long daylength and low light intensity $\left(16 \mathrm{~h}\right.$ of $\left.215 \mu \mathrm{mol} \cdot \mathrm{s}^{-1} \cdot \mathrm{m}^{-2}\right)$, and long daylength and high light intensity $\left(16 \mathrm{~h}\right.$ of $\left.435 \mu \mathrm{mol} \cdot \mathrm{s}^{-1} \cdot \mathrm{m}^{-2}\right)$.

\begin{tabular}{|c|c|c|}
\hline \multirow[b]{2}{*}{ Daylength } & \multicolumn{2}{|c|}{ Anthocyanin concn $\left[\right.$ mean $\pm \mathrm{SE}\left(\right.$ pixels $\left.\left./ \mathrm{mm}^{2}\right)\right]$} \\
\hline & $\begin{array}{l}\text { Low light } \\
\text { intensity }\end{array}$ & $\begin{array}{l}\text { High light } \\
\text { intensity }\end{array}$ \\
\hline Short day & $34 \pm 9 \mathrm{a}^{\mathrm{z}}$ & $613 \pm 116 \mathrm{c}$ \\
\hline Long day & $361 \pm 100 \mathrm{~b}$ & $594 \pm 53 \mathrm{c}$ \\
\hline
\end{tabular}

${ }^{\mathrm{z}}$ Means followed by the same letter within an individual light treatment are not significantly different according to the Tukey comparison test $(P=0.001)$.

(Table 3). Structural gene expression, as expected, correlated with anthocyanin accumulation. There was a statistically significant increase in Chs, $D f r$, and $A n s$ gene expression in progressively older leaves. Because there was more anthocyanin in mature leaves under higher temperatures, all further studies used mature leaves.

To explain the genetic basis for the effects of light and temperature on anthocyanin pigmentation, we measured Chs, Dfr, and Ans expression in leaves from plants grown under low $\left(20^{\circ} \mathrm{C} / 15^{\circ} \mathrm{C}\right)$ or high temperatures $\left(30^{\circ} \mathrm{C} / 25^{\circ} \mathrm{C}\right)$ temperatures at low $\left(10 \mathrm{~h}\right.$ of $\left.215 \mu \mathrm{mol} \cdot \mathrm{s}^{-1} \cdot \mathrm{m}^{-2}\right)$ or high $(16 \mathrm{~h}$ of $435 \mu \mathrm{mol} \cdot \mathrm{s}^{-1} \cdot \mathrm{m}^{-2}$ ) light conditions (Table 4$)$. The anthocyanin structural gene (Chs, Dfr, and $A n s)$ expression behaved in a similar manner as anthocyanin accumulation. Temperature had no effect on their expression under either high or low light conditions, whereas light positively influenced their expression under both low and high temperature conditions (Table 4). Structural gene expression increased about two to fourfold in response to higher light conditions.

To explain the genetic regulation of the structural genes under inductive and noninductive environments, $M y c, M y b_{A}$, and $W d 40$ expression was measured. Under low light conditions, temperature had no effect on $M y c, M y b_{A}$, and $W d 40$ expression; under high light conditions, temperature only had an effect on $M y b_{A}$ expression (Table 5).

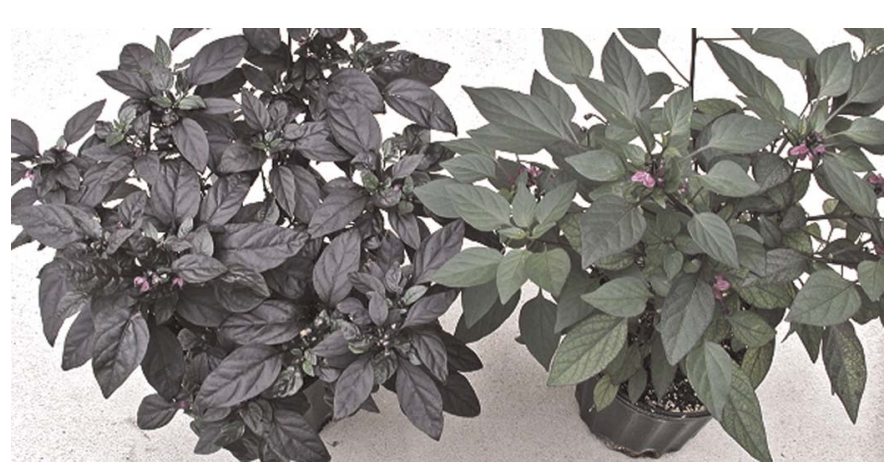

Fig. 1. (A, B) Foliar anthocyanin pigmentation in Capsicum annuum 'G02C27' plants grown under either high light intensity and high temperature $[16 \mathrm{~h}$ of $435 \mu \mathrm{mol} \cdot \mathrm{s}^{-1} \cdot \mathrm{m}^{-2} ; 30{ }^{\circ} \mathrm{C}$ day $\left./ 25{ }^{\circ} \mathrm{C}(\mathrm{A})\right]$ or low light intensity and low temperature $\left[10 \mathrm{~h}\right.$ of $215 \mu \mathrm{mol} \cdot \mathrm{s}^{-1} \cdot \mathrm{m}^{-2} ; 20^{\circ} \mathrm{C}$ day $/ 15^{\circ} \mathrm{C}$ night (B)].
Table 3. The relative fold expression of anthocyanin structural genes in Capsicum annuum ' $\mathrm{G} 02 \mathrm{C} 27^{\circ}$ ' leaves from four developmental stages in plants grown at $30{ }^{\circ} \mathrm{C}$ day $/ 25^{\circ} \mathrm{C}$ night.

\begin{tabular}{lccc}
\hline & \multicolumn{3}{c}{ Relative fold expression (mean $\pm \mathrm{SE}$ ) } \\
\cline { 2 - 4 } Stage & Chs & Dfr & Ans \\
\hline Stage 1 & $1.28 \pm 0.01 \mathrm{a}^{\mathrm{z}}$ & $1.18 \pm 0.01 \mathrm{a}$ & $1.00 \pm 0.02 \mathrm{a}$ \\
Stage 2 & $1.26 \pm 0.02 \mathrm{a}$ & $1.19 \pm 0.01 \mathrm{a}$ & $1.01 \pm 0.01 \mathrm{a}$ \\
Stage 3 & $1.31 \pm 0.01 \mathrm{~b}$ & $1.24 \pm 0.01 \mathrm{~b}$ & $1.07 \pm 0.01 \mathrm{c}$ \\
Stage 4 & $1.34 \pm 0.01 \mathrm{c}$ & $1.28 \pm 0.01 \mathrm{c}$ & $1.04 \pm 0.01 \mathrm{~b}$ \\
\hline
\end{tabular}

${ }^{\mathrm{z}}$ Means followed by the same letter are not significantly different using Fisher's LSD pairwise multiple comparison test $(P \leq 0.001)$.

Stage 1 was defined as an immature, 1 -cm-long leaf and stage 4 was a fully expanded leaf three internodes below the stage 1 leaf. Stages 2 and 3 leaves were the corresponding leaves at internodes 1 and 2. All plants were grown under $16 \mathrm{~h}$ of $435 \mu \mathrm{mol} \cdot \mathrm{s}^{-1} \cdot \mathrm{m}^{-2}$ cool-white fluorescent light supplemented with incandescent light. Gene expression was measured as the normalized expression to tubulin. Data are presented as the mean from three replicates: Ans, anthocyanin synthase; Chs, chalcone synthase; $D f r$, dihydroflavonol reductase.

\section{Discussion}

Anthocyanin pigmentation in $C$. annuum fruit is transient. Violet-to-black fruit pigmentation is typically limited to immature fruit, although anthocyanin retention may be observed in mature fruit in conjunction with carotenoids (Stommel and Bosland, 2006). In contrast with fruit tissue, anthocyanin pigmentation is normally stable through plant development in leaves, stems, flowers, and other plant organs of those genotypes that exhibit anthocyanin accumulation. Similar to anthocyanin pigmentation of $C$. annuum foliage, variation in intensity of anthocyanin pigmentation occurs in these tissues. Environmental conditions can influence the degree of anthocyanin pigmentation.

We observed that leaves from $C$. annuum plants grown under a long duration of high-intensity light had more anthocyanin pigmentation than plants grown under lower light conditions. This is similar to results found in other species. In the leaves of the red-leaf form of Pennistem setaceum Rich., the amount of anthocyanin increased as the daily light integral (measured in moles per square meter per d) increased (Beckwith et al., 2004). Similarly, high light intensity increased leaf anthocyanin pigmentation in Galax urceolta L. leaves (Hughes et al., 2005) and Ipomoea batatas Lam. leaves (Shahidul et al., 2005).

Our results demonstrated that the temperature had no affect on the anthocyanin content of leaves from $C$. annuum plants grown under either low or high light conditions. Different species respond differently to temperature. For example, both I. batatas (Shahidul et al., 2005) and Lactuca sativa L. (Gazula et al., 2005) leaves had higher levels of anthocyanin when grown at $20{ }^{\circ} \mathrm{C}$ versus $30{ }^{\circ} \mathrm{C}$. Similarly, Zea mays L. leaves had higher levels of anthocyanin when grown at $15^{\circ} \mathrm{C}$ versus $25^{\circ} \mathrm{C}$ (Christie et al., 1994). Whereas on the other hand, Brassica oleracea L. leaves had lower levels of anthocyanin when grown at $14{ }^{\circ} \mathrm{C}$ versus $25^{\circ} \mathrm{C}$ (Rabino and Mancinelli, 1986).

We observed that structural gene expression, as expected, correlated with anthocyanin accumulation. Under both high and low light conditions, temperature had no significant effect on expression of Chs, Dfr, and Ans. While under both high and low temperature conditions, higher light conditions positively 
Table 4. The relative fold expression of flavonoid structural genes in mature Capsicum annuum 'G02C27' leaves under high light versus low light $\left(16 \mathrm{~h}\right.$ of $435 \mu \mathrm{mol} \cdot \mathrm{s}^{-1} \cdot \mathrm{m}^{-2}$ vs. $10 \mathrm{~h}$ of $215 \mu \mathrm{mol} \cdot \mathrm{s}^{-1} \cdot \mathrm{m}^{-2}$ ) and high temperature versus low temperature $\left(30^{\circ} \mathrm{C} / 25^{\circ} \mathrm{C}\right.$ vs. $20^{\circ} \mathrm{C}$ day $/ 15^{\circ} \mathrm{C}$ night $)$. Gene expression was measured as the normalized expression to tubulin. Data are presented as the mean from three replicates: Ans, anthocyanin synthase; $C h s$, chalcone synthase; $D f r$, dihydroflavonol reductase.

\begin{tabular}{|c|c|c|c|c|c|c|}
\hline \multirow[b]{3}{*}{ Light } & \multicolumn{6}{|c|}{ Relative fold expression (mean $\pm \mathrm{SE}$ ) } \\
\hline & \multicolumn{2}{|c|}{ Chs } & \multicolumn{2}{|c|}{$D f r$} & \multicolumn{2}{|c|}{ Ans } \\
\hline & Low & High & Low & High & Low & High \\
\hline High & $6.67 \pm 1.25 \mathrm{~b}$ & $6.48 \pm 0.26 \mathrm{~b}$ & $4.79 \pm 1.01 \mathrm{~b}$ & $6.06 \pm 0.26 \mathrm{~b}$ & $3.88 \pm 1.15 \mathrm{~b}$ & $4.99 \pm 0.75 b$ \\
\hline
\end{tabular}

${ }^{\mathrm{z}}$ Means followed by the same letter are not significantly different according to Fisher's LSD pairwise multiple comparison test $(P \leq 0.001)$.

influenced Chs, Dfr, and Ans expression (Table 4). Regulatory gene expression had a constant level of expression in all treatments, except that $M y b_{A}$ expression was higher under low temperature/high light conditions (Table 5).

There are many reports describing the effects of light on anthocyanin gene expression (Fuglevand et al., 1996; Kawabata et al., 1999; Koes et al., 1989; Procissi et al., 1997; Takos et al., 2006; Taylor and Briggs, 1990; Toguri et al., 1993). All these studies demonstrated that anthocyanin gene expression was light inducible. Depending upon the species and the tissue, either ultraviolet B, ultraviolet A, or blue light upregulated expression. In hypocotyls from Solanum melongena L. plants grown under red light (610-800 nm), Chs and $D f r$ transcripts were only detected after exposure to white light from cool-white fluorescence lamps (Toguri et al., 1993). In $Z$. mays seedlings, light-induced structural gene expression was the result of an increase in $M y c$ transcript concentration (Taylor and Briggs, 1990). Under high-intensity white light $\left(1200 \mu \mathrm{mol} \cdot \mathrm{m}^{-2}, 290-800 \mathrm{~nm}\right)$, there was nearly a $25 \%$ increase in Z. mays Myc transcription levels compared with lowintensity red light $\left(2 \mu \mathrm{mol} \cdot \mathrm{m}^{-2}, 619-800 \mathrm{~nm}\right)$. Our data are consistent with these results.

In this study, a difference in regulatory gene expression was not responsible for the difference in structural gene expression under inductive and noninductive environmental conditions for anthocyanin accumulation. One possible mechanism that may explain these results involves microRNA (miRNA). MicroRNAs control gene expression by targeting specific messenger RNAs (mRNAs) for degradation (Bartel, 2004; Jones-Rhoades et al., 2006; Kidner and Marteinssen, 2005). The $3^{\prime}$ end of an miRNA binds to a protein complex [RNA-induced silencing complex (RISC)] that aligns it with its target mRNA, which also binds to the RISC. The mRNA is then cleaved between the 10th and 11th bases from the $5^{\prime}$ end of the miRNA match and further degraded by exoribonuclease 4 .
Preliminary observations suggest that miRNAs could be involved in regulating anthocyanin gene expression in $C$. annuum leaves. One of the symptoms we observed after tobacco etch virus infection of purple-leaf $C$. annuum plants was a reduction in anthocyanin pigmentation (data not shown). In addition, $C$. annuum fruit from virus-infected plants can display differential anthocyanin pigmentation (Black et al., 1991). Viral infection is known to modify host gene expression by suppressing RNA silencing. Glycine max L. seeds are yellow as a result of the presence of Chs miRNAs (Senda et al., 2004). When infected with soybean mosaic potyvirus, there was an increase in Chs mRNA that restored anthocyanin seed color. Further studies are planned to examine miRNA expression under inductive and noninductive conditions.

The influence of miRNA on gene expression could be one of the mechanisms for the genotype-by-environment interaction. The genotype-by-environment interaction is a result of the nonreciprocal interaction of nonallelic genes or epistasis (Rieger et al., 1976). Epistatic gene interactions are manifested in phenotypic plasticity. Two simplified genetic models account for the genetic basis of phenotypic plasticity: 1) the direct effect of the environment on structural gene expression wherein all loci are expressed in different environments but individual alleles vary in their sensitivity and 2) regulatory gene control wherein gene expression is controlled via the action of regulatory genes that control the differential expression of multiple structural genes (Scheiner, 1993; Schlichting and Pigliucci, 1993).

Traditionally, statistical procedures are used to measure genotype-by-environment interactions (i.e., epistasis) and the resulting phenotypic plasticity. In our study, a molecular approach to understanding epistasis and plasticity was used. The study of anthocyanin leaf pigmentation in C. annuum under inductive and noninductive environments provides a new approach for elucidating the molecular genetic basis of epistatic gene interactions.

Table 5. The relative fold expression of flavonoid regulatory genes in mature Capsicum annuum 'G02C27' leaves grown under high light versus low light $\left(16 \mathrm{~h}\right.$ of $435 \mu \mathrm{mol} \cdot \mathrm{s}^{-1} \cdot \mathrm{m}^{-2}$ versus $10 \mathrm{~h}$ of $\left.215 \mu \mathrm{mol} \cdot \mathrm{s}^{-1} \cdot \mathrm{m}^{-2}\right)$ and high temperature versus low temperature $\left(30^{\circ} \mathrm{C}\right.$ day $/ 25^{\circ} \mathrm{C}$ night vs. $20{ }^{\circ} \mathrm{C}$ day $/ 15^{\circ} \mathrm{C}$ night). Gene expression was measured as the normalized expression to tubulin. Data are presented as the mean from three replicates: $M y c, \mathrm{MYC}_{\mathrm{An} 1}$ transcription factor; $M y b, \mathrm{MYB}_{\mathrm{An} 2}$ transcription factor; $W d 40, \mathrm{WD}_{\mathrm{An} 11}$ transcription factor.

\begin{tabular}{|c|c|c|c|c|c|c|}
\hline \multirow[b]{4}{*}{ Light } & \multicolumn{6}{|c|}{ Relative fold expression (mean $\pm \mathrm{SE}$ ) } \\
\hline & \multicolumn{2}{|c|}{$M y b$} & \multicolumn{2}{|c|}{$M y c$} & \multicolumn{2}{|c|}{$W d 40$} \\
\hline & \multicolumn{2}{|c|}{ Temperature } & \multicolumn{2}{|c|}{ Temperature } & \multicolumn{2}{|c|}{ Temperature } \\
\hline & Low & High & Low & High & Low & High \\
\hline High & $3.51 \pm 0.37 \mathrm{~b}$ & $1.80 \pm 0.17 \mathrm{a}$ & $1.05 \pm 0.12 \mathrm{a}$ & $1.29 \pm 0.19 \mathrm{a}$ & $2.05 \pm 0.64 \mathrm{a}$ & $3.08 \pm 0.98 \mathrm{a}$ \\
\hline
\end{tabular}

${ }^{\mathrm{z}}$ Means followed by the same letter are not significantly different according to Fisher's LSD pairwise multiple comparison test $(P \leq 0.001)$. 


\section{Literature Cited}

Bartel, D.P. 2004. MicroRNAs: Genomics, biogenesis, mechanism and function. Cell 16:281-297.

Baudry, A., M. Caboche, and L. Lepiniec. 2006. TT8 controls its own expression in a feedback regulation involving TTG1 and a homologous MYB and bHLH factors, allowing a strong and cell specific accumulation of flavonoids in Arabidopsis thaliana. Plant J. 46: 768-779.

Beckwith, A.G., Y. Zhang, N.P. Seeram, A.C. Cameron, and M.G. Nair. 2004. Relationship of light quality and anthocyanin production in Pennisetum setaceum cvs. Rubrum and Red Riding Hood. J. Agr. Food Chem. 52:456-461.

Black, L.L., S.K. Green, G.L. Hartman, and J.M. Poulus. 1991. Pepper diseases: A field guide. Asian Veg. Res. Dev. Center, Taipei, Taiwan. Borevitz, J.O., Y. Xia, J. Blount, R.A. Dixon, and C. Lamb. 2000. Activation tagging identifies a conserved MYB regulatory gene of phenylpropanoid biosynthesis. Plant Cell 12:2383-2393.

Borovsky, Y., M. Oren-Shamir, R. Ovadia, W. deJong, and I. Paran. 2004. The $A$ locus that controls anthocyanin accumulation in pepper encodes a $M Y B$ transcription factor homologous to Anthocyanin2 of Petunia. Theor. Appl. Genet. 109:23-29.

Buck, M.J. and W.R. Atchley. 2003. Phylogenetic analysis of plant basic helix-loop-helix proteins. J. Mol. Evol. 56:742-750.

Christie, P.J., M.R. Alfenito, and V. Walbot. 1994. Impact of lowtemperature stress on general phenylpropanoid and anthocyanin pathways: Enhancement of transcript abundance and anthocyanin pigmentation in maize seedlings. Planta 194:541-549.

Deshpande, R.B. 1933. Studies in Indian chilies. 3. The inheritance of some characters in Capsicum annuum L. Indian J. Agr. Sci. 3:219-300.

Fuglevand, G., J.A. Jackson, and G.I. Jenkins. 1996. UV-B, UV-A, and blue light signal transduction pathways interact synergistically to regulate chalcone synthase gene expression in Arabidopsis. Plant Cell 8:2347-2357.

Gazula, A., M.D. Kleinhenz, J.G. Streeter, and A.R. Miller. 2005. Temperature and cultivar effects on anthocyanin and chlorophyll b concentrations in three related lollo rosso lettuce cultivars. HortScience 40:1731-1733.

Griesbach, R.J. 2005. Biochemistry and genetics of flower color. Plant Breed. Rev. 25:89-114.

Griesbach, R.J. and R.M. Beck. 2005. Sequence analysis of the chalcone synthase gene in four Petunia L. taxa. J. Amer. Soc. Hort. Sci. 130:360-365.

Hartmann, U., M. Sagasser, F. Mehrtens, R. Stracke, and B. Weisshaar. 2005. Differential combinatorial interactions of cis-acting elements recognized by R2-R3-Myb, BZIP and BHLH factors control light responsive and tissue specific activation of phenylpropanoid biosynthesis genes. Plant Mol. Biol. 57:155-171.

Hernandez, J.M., G.F. Heine, N.G. Irani, A. Feller, M.G. Kim, T. Matulnik, V.L. Chandler, and E. Grotewold. 2004. Different mechanisms participate in the R-dependent activity of the R2R3 MYB transcription factor C1. J. Biol. Chem. 279:48205-48213.

Hughes, N.M., H.S. Neufeld, and K.O. Burkey. 2005. Functional role of anthocyanins in high-light leaves of the evergreen herb Galix ureolata. New Phytol. 68:575-587.

Jones-Rhoades, M.W., D.P. Bartel, and B. Bartel. 2006. MicroRNAs and their regulatory roles in plants. Annu. Rev. Plant Biol. 57:19-53.

Kawabata, S., Y. Kusuhara, Y. Li, and R. Sakiyama. 1999. The regulation of anthocyanin biosynthesis in Eustoma grandiflorum under low light conditions. J. Jpn. Soc. Hort. Sci. 68:519-526.

Kidner, C.A. and R.A. Marteinssen. 2005. The developmental role of microRNA in plants. Curr. Opin. Plant Biol. 8:39-44.

Koes, R.E., E. Cornelis, J. Spelt, and J.N.M. Mol. 1989. The chalcone synthase multigene family of Petunia hybrida (V30): Differential, light-regulated expression during flower development and UV light induction. Plant Mol. Biol. 12:213-225.
Lightbourn, G.J., R.J. Griesbach, J.A. Novotny, B.A. Clevidence, and J.R. Stommel. 2007. Effects of anthocyanin and carotenoid combinations on foliage and immature fruit color of Capsicum. J. Hered. (in press).

Nijveldt, R.J., E. van Nood, D.E.C. van Hoorn, P.G. Boelens, K. van Norren, and P.A.M. van Leeuwen. 2001. Flavonoids: A review of probable mechanisms of action and potential applications. Amer. J. Clin. Nutr. 74:418-425.

Peterson, P.A. 1959. Linkage of fruit shape and color genes in pepper. Genetics 44:407-419.

Pfaffl, M.W. 2001. A new mathematical model for relative quantification in real-time RT-PCR. Nucl. Acids Res. 29:20022007.

Procissi, A., S. Dolfini, A. Ronchi, and C. Tonelli. 1997. Lightdependent spatial and temporal expression of pigment regulatory genes in developing maize seeds. Plant Cell 9:1547-1557.

Rabino, I. and A.L. Mancinelli. 1986. Light, temperature, and anthocyanin production. Plant Physiol. 81:922-924.

Ramsay, N.A. and B.J. Glover. 2005. MYB-bHLH-WD40 protein complex and the evolution of cellular diversity. Trends Plant Sci. 10:63-70.

Rieger, R., A. Michaelis, and M.M. Green. 1976. Glossary of genetics and cytogenetics. Springer-Verlag, Berlin.

Scheiner, S.M. 1993. Genetics and evolution of phenotypic plasticity. Annu. Rev. Ecol. Evol. Systematics 24:35-68.

Schlichting, C.D. and M. Pigliucci. 1993. Control of phenotypic plasticity via regulatory genes. Amer. Naturalist 142:366-370.

Senda, M., C. Masuta, S. Ohnishi, K. Goto, A. Kasai, T. Sano, J.-S. Hong, and S. MacFarlane. 2004. Patterning of virus-infected Glycine max seed coat is associated with suppression of endogenous silencing of chalcone synthase genes. Plant Cell 16:807-818.

Shahidul, I., M. Jalaluddin, J.O. Garner, M. Yoshimoto, and O. Yamakawa. 2005. Artificial shading and temperature influence on anthocyanin compositions in sweet potato leaves. HortScience 40:176-180.

Sheridan, P. and R. Mills. 1998. Presence of proanthocyanidins in mutant green Sarracenia indicate blockage in late anthocyanin biosynthesis between leucoanthocyanin and pseudobase. Plant Sci. 135:11-16.

Smith, T.F. 1999. The WD repeat: A common architecture for diverse functions. Trends Biochem. Sci. 24:181-185.

Stommel, J.R. and P.W. Bosland. 2006. Ornamental pepper, Capsicum annuum, p. 561-599. In: N.O. Anderson (ed.). Flower breeding and genetics: Issues, challenges, and opportunities for the 21 st century. Springer-Verlag, Berlin.

Stracke, R., M. Werber, and B. Weisshaar. 2001. The R2R3-MYB gene family in Arabidopsis thaliana. Curr. Opin. Plant Biol. 4:447456.

Takos, A.M., F.W. Jaffeì, S.R. Jacob, J. Bogs, S.P. Robinson, and A.R. Walker. 2006. Light-induced expression of a MYB gene regulates anthocyanin biosynthesis in red apples. Plant Physiol. 142:12161232.

Taylor, L.P. and W.R. Briggs. 1990. Genetic regulation and photocontrol of anthocyanin accumulation in maize seedlings. Plant Cell $2: 115-127$.

Toguri, T., N. Umemoto, O. Kobayashi, and T. Ohtani. 1993. Activation of anthocyanin synthesis genes by white light in eggplant hypocotyl tissues, and identification of an inducible P-450 cDNA. Plant Mol. Biol. 23:933-946.

Winkel-Shirley, B. 2001. Flavonoid biosynthesis: A colorful model for genetics, biochemistry, cell biology, and biotechnology. Plant Physiol. 126:485-493.

Zimmermann, I.M., M.A. Heim, B. Weisshaar, and J.F. Uhrig. 2004. Comprehensive identification of Arabidopsis thaliana MYB transcription factors interacting with R/B-like BHLH proteins. Plant J. 40:22-34. 